\title{
Effects of Chlordane and Lindane on Testosterone and Vitellogenin Levels in Green Neon Shrimp (Neocaridina denticulata)
}

\author{
Da-Ji Huang' and Hon-Cheng Chen ${ }^{2}$ \\ ${ }^{1}$ Institute of Zoology and ${ }^{2}$ Institute of Fisheries Sciences, \\ National Taiwan University, Taipei, Taiwan, Republic of China
}

\begin{abstract}
The purpose of this study was to investigate the acute toxicity of chlordane and lindane as well as their endocrine disruption effect on green neon shrimp (Neocaridina denticulata), a common habitant in freshwater system of eastern Asia and Hawaii. First, the organisms were exposed to chlordane and lindane to estimate the 96-h $\mathrm{LC}_{50}(96-\mathrm{h}$ median lethal concentration). Then, levels of testosterone and vitellogenin in hemolymph of $N$. denticulata after exposure to sublethal concentrations of chlordane $(1 \mathrm{ng} / \mathrm{L}$ and $10 \mathrm{ng} / \mathrm{L})$ and lindane $(0.1 \mu \mathrm{g} / \mathrm{L}$ and $1 \mu \mathrm{g} / \mathrm{L})$ were also examined. The 96-h $\mathrm{LC}_{50}$ values obtained from the results of acute exposure were 127.03 (130.11-122.35) $\mathrm{ng} / \mathrm{L}$ and $9.36(8.00-10.96) \mu \mathrm{g} / \mathrm{L}$ for chlordane and lindane, respectively. Furthermore, reductions of testosterone concentration were observed in both chlordane- and lindane-treated shrimps, whereas induction of vitellogenin-like protein was only apparent in chlordane-treated shrimps. Thus, it is concluded that chlordane and lindane may probably show some disruption endocrine functions on $\boldsymbol{N}$. denticulata.
\end{abstract}

Keywords Chlordane, Endocrine Disruption Chemicals, Lindane, Neocaridina denticulata, Testosterone, Vitellogenin

Chlordane and lindane, being organochlorine pesticides (OCPs), have been extensively used over the last two decades. OCPs are some of the most dangerous pesticides due to their toxicity, stability, high liposolubility, and long biological half-life. OCPs exhibit a high degree of bioaccumulation and biomagnification within the food chain, and these chemicals are known to be carcinogenic, teratogenic, and have endocrine disrupting activity in humans and wildlife (Klaassen 2001). Therefore, many developing and developed countries have prohibited the use of

Received 21 October 2003; accepted 13 January 2004.

Thanks are due to Dr. Shu-Yin Wang for reading the manuscript and making a number of helpful suggestions.

Address correspondence to Dr. Hon-Cheng Chen, Room 605, Institute of Zoology, National Taiwan University No. 1 Sec. 4, Roosevelt Road, Taipei 106, Taiwan, Republic of China. E-mail: honcheng@ ccms.ntu.edu.tw these compounds for many years, even though OCPs are still being detected in ecosystems (Chen, Wang, and Yaun 1999). Both chlordane and lindane are reported to have symptoms similar to endocrine disrupting chemicals (EDCs) (Colborn, vom Saal, and Soto 1993). In animal studies, these compounds have been shown to actually mimic estrogen (xenoestrogen) and to cause detrimental effects on reproductive systems (Colborn, vom Saal, and Soto 1993; Keith 1997). The US Environmental Protection Agency (EPA) has designated that chlordane is a probable human carcinogen, causing hepatic tumors as well as acute leukemia in mammals. Prenatal mice exposed to chlordane exhibited immunotoxic effects and caused uterus toxicity (Keith 1997). Much literature exists showing that lindane exerts neurotoxic, hepatotoxic, and uterotoxic effects (Keith 1997).

Invertebrates (especially arthropods such as insects and crustaceans) constitute the vast majority of animal species on earth, and represent an important and diverse group within the crustaceans. The populations of crustaceans often rely on the water quality and food supply. Consequently, their populations also influence the fish production in ecosystem (Dodson 1989). Therefore, examining the ecological characteristics of crustaceans will facilitate our understanding of ecology, because of their key positions in communities (Dodson 1989; Dodson, Hanazato, and Gorski 1995). Due to the increasing serious water pollution, the environment also contains anthropogenic toxicants, which affect the biota in complex and synergistic ways. Although toxicity test protocols of many invertebrate are routinely used in regulatory toxicity testing, few have been designed with endocrine-specific end point in mind. The objective of this study was to examine the toxicity of chlordane and lindane in green neon shrimp (Neocaridina denticulata), a species extensively distributed in rivers throughout eastern Asia and Hawaiian Island (Englund and Cai 1999; Hung, Chan, and Yu 1993). Our hypothesis was that testosterone and vitellogenin $(\mathrm{Vg})$ levels in the bodies of $N$. denticulata can change after exposure to chlordane and lindane to show their endocrine disrupting function. 


\section{MATERIALS AND METHODS}

\section{Animal Collection and Maintenance}

Green neon shrimp ( $N$. denticulata) of 9 to $12 \mathrm{~mm}$ body length were taken from rivers in Taipei County for laboratory testing. They were transferred to a $50-\mathrm{L}$ glass aquarium after being identified. This aquarium was equipped with a water-cycling device, $\mathrm{pH}$ was maintained at 7.4 to 7.8 , dissolved oxygen concentration was greater than $7.3 \mathrm{mg} / \mathrm{L}$, and hardness was 38 to $45 \mathrm{mg} \mathrm{CaCO} / \mathrm{L}$. Temperature was maintained at $25^{\circ} \mathrm{C} \pm 1^{\circ} \mathrm{C}$, and a 12-h light-dark photoperiod was used. Under these conditions, shrimp were fed twice a day and acclimated for 2 weeks before testing.

\section{Chemicals and Water Renewal}

Chlordane and lindane were purchased from Sigma (St. Louis, MO, USA). A stock solution of chlordane $(10 \mathrm{mg} / \mathrm{L})$ and lindane $(100 \mathrm{mg} / \mathrm{L})$ was prepared in acetone and stored in refrigeration $\left(4^{\circ} \mathrm{C}\right)$ for use. Toxicity tests with water renewal based on the Standard Guide for Conducting Acute Tests with Shrimps every 48 hours (EPA/ROC 1998).

\section{Establishment of Median Lethal Concentration}

Shrimp were divided into 10 groups ( 20 shrimp/group) in 5-L glass beakers and exposed to various pesticide concentrations as shown in Table 1. Each treatment was done in triplicate. During the experiment, dead individuals were removed and mortality of shrimp was recorded at the 2nd, 6th, 24th, 48th, 96th, and 120th h. Data obtained in this test were analyzed to estimate the 96-h LC $_{50}$ using the method of Finney (1972).

\section{Assays for Vitellogenin and Testosterone}

The 96-h median lethal concentration $\left(96-\mathrm{h} \mathrm{LC}_{50}\right)$ was the pilot study used for determining the pesticide concentrations for chronic studies. Sublethal concentrations of chlordane and lindane were 1 and $10 \mathrm{ng} / \mathrm{L}$ and 0.1 and $1 \mu \mathrm{g} / \mathrm{L}$, respectively. Experiments with positive controls $(10 \mu \mathrm{g} / \mathrm{L}$ and $1 \mathrm{mg} / \mathrm{L} 17 \beta$ estradiol in alcohol) and no pesticide added were also carried out, as well as those using a vehicle-control group in which only acetone was added. In total, there were 100 juvenile shrimp (body length 9 to $12 \mathrm{~mm}$ ) of same size in each group (in a $10-\mathrm{L}$ glass beaker, run in triplicate), and samples were taken at the end of days $1,3,7,14$, and 28 .

In preparation for vitellogenin-like protein and testosterone analysis, shrimp samples were homogenized with a Teflon pestle (Kontes, Vineland, NJ, USA) in ice-cold $25 \mathrm{mM}$ Tris- $\mathrm{HCl}$ with EDTA. The homogenate was centrifuged at $10,000 \times g$ (for $20 \mathrm{~min}$ at $4^{\circ} \mathrm{C}$ ), and the supernatant was collected and stored at $-20^{\circ} \mathrm{C}$ until analysis.

The level of vitellogenin-like protein in the hemolymph was mediate determined by using an alkali-labile phosphate (ALP) measurement assay and the quantity of ALP in hemolymph was obtained similar to the method of Gangé and Blaise (2000). Shrimp hemolymph (in 5 and $45 \mu \mathrm{l}$ of Tris- $\mathrm{HCl}$ buffer, $25 \mathrm{mM}$, $\mathrm{pH} 7.5$ ) was mixed with $50 \mu \mathrm{l}$ ice-cold $20 \%$ trichloroacetic acid (TCA) and incubated at room temperature for $15 \mathrm{~min}$. The mixture was centrifuged at $10,000 \times g$ for $10 \mathrm{~min}$ at $4^{\circ} \mathrm{C}$. The protein pellet was resuspended with $200 \mu 11 \mathrm{M} \mathrm{NaOH}$ and then heated to $75^{\circ} \mathrm{C}$ for $60 \mathrm{~min}$ before determination. The level of free phosphates was determined according to the phosphomolybdenum method, and the optical absorbance was read at $600 \mathrm{~nm}$.

TABLE 1

Pesticide concentrations and green neon shrimp (Neocaridina denticulata) mortality (\%) in acute toxicity and the $96-\mathrm{h} \mathrm{LC} 50$

\begin{tabular}{lccccc}
\hline Pesticide & $\begin{array}{c}\text { Average } \\
\text { shrimp weight } \\
(\mathrm{mg})\end{array}$ & $\begin{array}{c}\text { Average } \\
\text { shrimp length } \\
(\mathrm{mm})\end{array}$ & $\begin{array}{c}\text { Nominal } \\
\text { concentration* } \\
(\mu \mathrm{g} / \mathrm{L})\end{array}$ & $\begin{array}{c}\text { Mean } \\
\text { mortality } \\
(\%)\end{array}$ & $\begin{array}{c}96-\mathrm{h} \\
\mathrm{LC}_{50} \\
(\mu \mathrm{g} / \mathrm{L})\end{array}$ \\
\hline Chlordane & 11.8 & $10.2 \pm 1.4$ & 0 & 0 & 0.127 \\
& & & 0.005 & 10 & \\
& & & 0.01 & 15 & \\
& & & 0.03 & 17 & \\
Lindane & 11.9 & 0.1 & 22 & \\
& & & 0.3 & 100 & \\
& & & 0 & 0 & 9.36 \\
& & & 1 & 0 & \\
& & & 3 & 5 & \\
& & & 5 & 10 & \\
& & & 10 & 55 & \\
& & 20 & 90 & \\
& & 30 & 100 & \\
\end{tabular}

*The final concentrations were obtained from acetone solutions. 
Levels of testosterone were determined using an EIA Kit (Cayman, Ann Arbor, MI, USA). This assay is based on the competition between testosterone and a testosterone-acetylcholinesterase (AChE) conjugate (testosterone tracer) for a limited number of testosterone-specific rabbit antiserum binding sites (Pradelles, Grassi, and Maclouf 1985; Maxey, Maddipati, and Birkmeter 1992). The product of this enzymatic reaction has a distinct yellow color and peak absorbance at $405 \mathrm{~nm}$ detectable by spectrophotometer.

\section{Statistical Analysis}

Statistical analysis used Microcal Origin 6.0 software. (Northampton, MA, USA, 1999). Experimental and control values were compared using Student's $t$ test (paired assay, $p<.05$ ). Areas under the curves indicating quantities during the levels of testosterone testing were obtained via an integration method in Microcal Origin 6.0.

\section{RESULTS AND DISCUSSION}

The 96-h $\mathrm{LC}_{50}$ values obtained were 127.03 (130.11-122.35) $\mathrm{ng} / \mathrm{L}$ and $9.36(8.00-10.96) \mu \mathrm{g} / \mathrm{L}$ for chlordane and lindane, respectively (Table 1). Obviously the toxicity of chlordane to $N$. denticulata is more obvious than that of lindane. So far, there is only limited knowledge of the adverse effects of pesticides on N. denticulata. Galindo, Jasso, and Lizarraga (1996) reported that the values of $48-\mathrm{h} \mathrm{LC}_{50}$ for chlordane and lindane of 63.2 and $3.9 \mu \mathrm{g} / \mathrm{L}$ for white shrimp (Penaeus vannamei), respectively. In fish, Bansal et al. (1980) also demonstrated that 12 to $20 \mu \mathrm{g} / \mathrm{L}$ chlordane was the values of $\mathrm{LC}_{50}$ for the larvae of four species of freshwater carp. Therefore, with our results a wide range of toxicity exists for these pesticides in a variety of aquatic organisms as well as within species. However, it is clear that both pesticides exert more toxicity more toxic to shrimp than fish.

Values of hemolymph testosterone concentrations in $17 \beta$ estradiol, chlordane, and lindane-treated groups were significantly $(p<0.05)$ lower than those of the control group (Figure 1). This is especially noteworthy in the cases of $10 \mu \mathrm{g} / \mathrm{L}$ and $1 \mathrm{mg} / \mathrm{L} 17 \beta$-estradiol. That is, hemolymph testosterone concentrations showed a rapid drop in 3 days, then rose steadily during 7 to 28 days with treatments of $10 \mu \mathrm{g} / \mathrm{L} 17 \beta$-estradiol; treatment with $1 \mathrm{mg} / \mathrm{L} 17 \beta$-estradiol produced a slight decrease during the entire experimental period. On the 28 th day, testosterone concentrations were both close to $1.8 \mathrm{ng} / \mathrm{g}$ with treatments of $10 \mu \mathrm{g} / \mathrm{L}$ and $1 \mathrm{mg} / \mathrm{L} 17 \beta$-estradiol (Figure $1 b$ ). Our results show that the areas for the control and treatments with $10 \mu \mathrm{g} / \mathrm{L} 17 \beta$-estradiol, $1 \mathrm{mg} / \mathrm{L} 17 \beta$-estradiol, $1 \mathrm{ng} / \mathrm{L}$ chlordane, $10 \mathrm{ng} / \mathrm{L}$ chlordane, $0.1 \mu \mathrm{g} / \mathrm{L}$ lindane, and $1 \mu \mathrm{g} / \mathrm{L}$ lindane were $72.6,55.5,48.2,55.1,49.7,52.6$, and $49.51 \mathrm{ng} / \mathrm{g} / 28$ days, respectively. Thus, areas relative to the control for treatments with $10 \mu \mathrm{g} / \mathrm{L} 17 \beta$-estradiol, $1 \mathrm{mg} / \mathrm{L} 17 \beta$-estradiol, $1 \mathrm{ng} / \mathrm{L}$ chlordane, $10 \mathrm{ng} / \mathrm{L}$ chlordane, $0.1 \mu \mathrm{g} / \mathrm{L}$ lindane, and $1 \mu \mathrm{g} / \mathrm{L}$ lindane decreased by $23.6 \%, 33.6 \%, 24.1 \%, 31.6 \%, 27.6 \%$, and $31.8 \%$, respectively. These data showed that treatment with chlordane
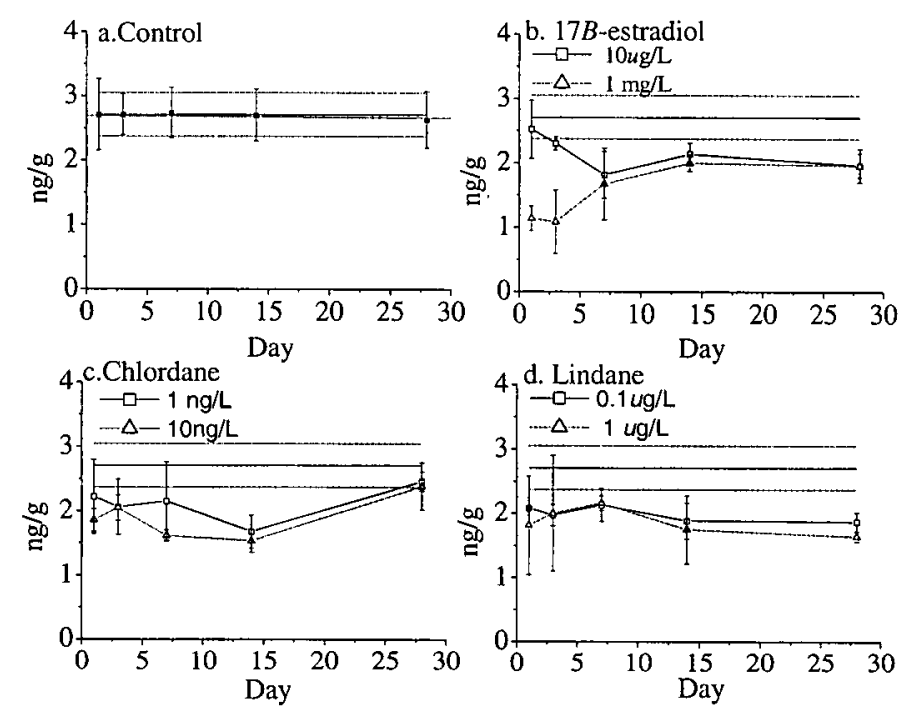

\section{FIGURE 1}

Hemolymph testosterone response levels in green neon shrimp exposed to $17 \beta$-estradiol $(b)$, chlordane $(c)$, and lindane $(d)$. The solid line shows the mean of control $(2.7 \mathrm{ng} / \mathrm{g})$, and dotted line shows $95 \%$ confidence limits $(3.1,2.4 \mathrm{ng} / \mathrm{g})$.

and lindane changed the levels of testosterone in the hemolymph, similar to that treated with $17 \beta$-estradiol as the positive control. This is good evidence proving that chlordane and lindane can result into the decrease the levels of testosterone in $N$. denticulata. The mechanistic of the decrease in testosterone is unknown. It is possible that the presence of xenoestrogen exert a feedback inhibition effect on the steroidogenesis. Another speculation is that aromatase may be activated to convert testosterone to estrogen.

Treatment with $17 \beta$-estradiol, chlordane, and lindane changed the levels of vitellogenin $(\mathrm{Vg})$ in the hemolymph, as determined by the ALP assays. $\mathrm{Vg}$ levels in $N$. denticulata hemolymph were induced from treatments with $17 \beta$-estradiol and chlordane on day 7 ; however, there were no significant differences $(p<.05)$ with the results from treatment with lindane (Figure 2). However, Vg determined by ALP assays may not reflect accurate measurement of $\mathrm{Vg}$, due to the present of phosphovitin-like protein and phosphovitin in addition to $\mathrm{Vg}$ in the hemolymph. However, it could be conceded as simple and time saving way to determine $\mathrm{Vg}$. An enzyme-linked immunosorbent assay (ELISA) assay can be used for the future study.

Our study shows that the testosterone levels of $N$. denticulata can be affected by chlordane and lindane. The male gonad was found to be a highly sensitive target organ for lindane (Silvestroni and Palleschi 1999). This phenomenon was also observed in results of treatments of the lindane group in this study. Although the concentration of testosterone in the chlordane group was initially shown to be inhibited, its level had risen by the 28 th day during the experimental period. Therefore, it is concluded that chlordane did not directly affect the testosterone levels of 

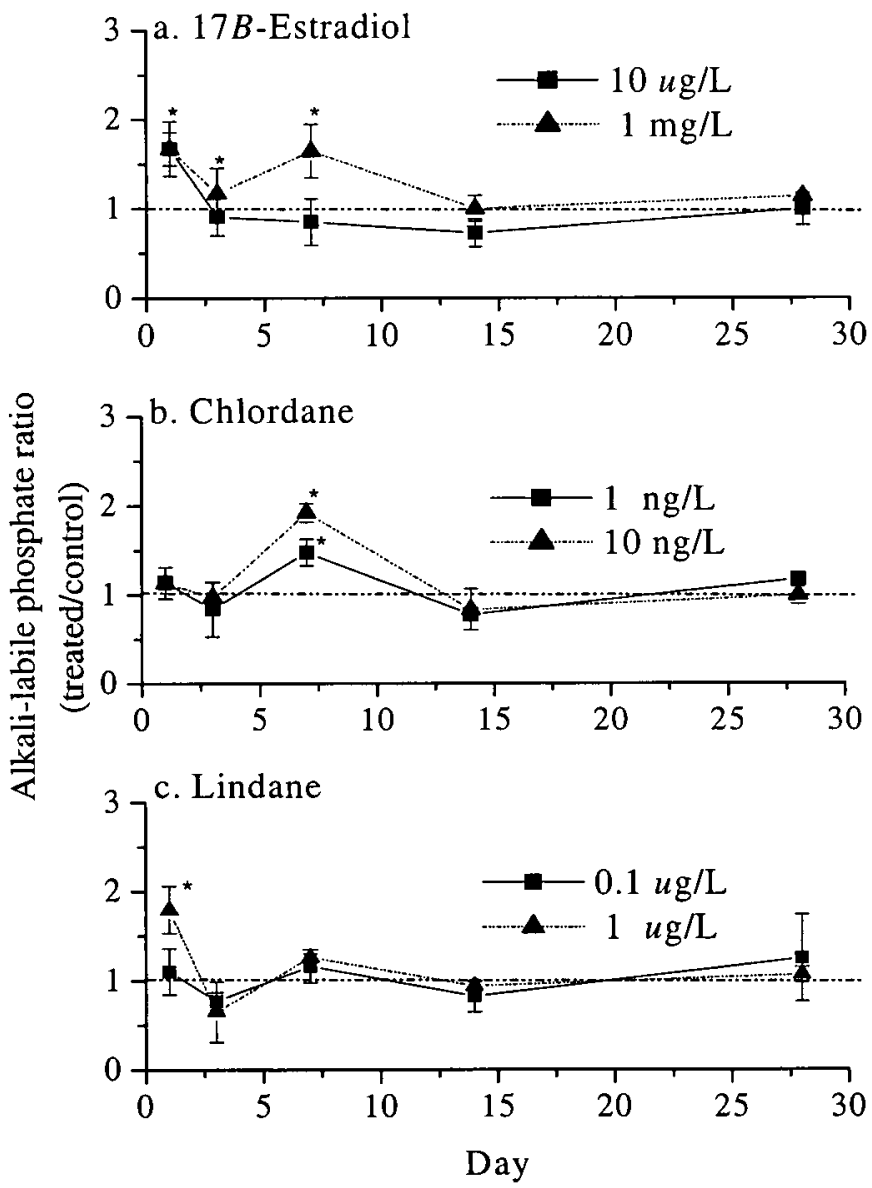

FIGURE 2

Hemolymph APL response levels in green neon shrimp exposure to $17 \beta$-estradiol $(a)$, chlordane $(b)$, and lindane $(c)$.

Asterisk $\left(^{*}\right)$ indicates significant differences between experimental and control at $p<.05$.

$N$. denticulata. On the other hand, the results of this study showed that chlordane caused an increase in $\mathrm{Vg}$ concentration, as did $17 \beta$-estradiol (the positive control). Under normal circumstances, a mature female organism usually shows a high level of estrogen, which can induce the $\mathrm{Vg}$ synthesis, whereas a male or immature individual shows a much lower level of estrogen, which cannot trigger the synthesis. However, things become different when the male or immature organism is exposed to the xenoestrogne, that is, $\mathrm{Vg}$ synthesis can probably be induced via the binding of xenoestrogne to estrogen receptors (Kime, Nash, and Scott 1999). It is speculated that the increased $\mathrm{Vg}$ synthesis may be related to the activation of hepatopancreas estrogen receptor (Tseng et al. 2001). In our study, we observed the $\mathrm{Vg}$ synthesis in a chlordane-treated group on $N$. denticulata, and therefore chlordane probably had an estrogenic effect on $N$. denticulata. As for lindane, although there was no significant difference shown in the statistics, this was probably either because the dose applied could not induce $\mathrm{Vg}$ synthesis or because the lindane had no effect on the estrogen receptor of $N$. dentic- ulata. Anyhow, our present studies showed that chlordane and lindane may probably have some disruption endocrine functions on $N$. denticulata.

Hormones control male and female reproductive systems (Hasegawa and Hirose 1993; Taylor and Harrison 1999). Literature on the basic endocrinology of crustaceans, such as crab, lobster, and shrimp, suggests that estrogens, e.g., $17 \beta$-estradiol, are stimulating hormones for female sexual maturation and egg laying (Andersen, Halling-Sørensen, and Kusk 1999). However, low concentrations of chlordane $(<14.2 \mu \mathrm{g} / \mathrm{L})$ and lindane $(<20.6 \mathrm{ng} / \mathrm{L})$ can still be detected in freshwater (Abou-Arab et al. 1995; Chen, Wang, and Yaun 1999; Galindo et al. 1999). When chemicals such as chlordane and lindane reach wildlife through the food chain, they may cause reproductive problems. As a result, decreases in wildlife populations could be well expected (Colborn, vom Saal, and Soto 1993). This is an urgency needing our attention to find out the biologically safe concentration if the reproductive systems and behaviors of $N$. denticulata in our environment are not to be changed. We are currently working on related studies to further understand the effects of chlordane and lindane on $N$. denticulata.

\section{REFERENCES}

Abou-Arab, A. A. K., M. N. E. Gomaa, A. Badawy, and K. Naguib. 1995 Distribution of organochlorine pesticides in the Egyptian aquatic ecosystem. Food Chem. 54:141-146.

Andersen, H. R., B. Halling-Sørensen, and O. K. Kusk. 1999. A parameter for detecting estrogenic exposure in the copepod acartia tonsa. Ecotoxicol. Environ. Saf. 44:56-61.

Bansal, S. K., S. R. Verma, A. K. Gupta, and R. C. Dalela. 1980. Predicting long-term toxicity by subacute screening of pesticides with larvae and early juveniles of four species of freshwater major carp. Ecotoxicol. Environ. Saf. 4:224-231.

Chen, H. C., Y. S. Wang, and J. H. Yaun. 1999. Standard methods to study and detect the bioaccumulation of in fish and shellfish (EPA-88-1502-03-01). Taiwan, Taipei: Environmental Protection Administration of Taiwan.

Colborn, T., F. S. vom Saal, and A. M. Soto. 1993. Developmental effects of endocrine disrupting chemicals in wildlife and humans. Environ. Health Perspect. 101:378-384.

Dodson, S. I. 1989. Predator-induced reaction norms. Bioscience 39:447-452.

Dodson, S. I., T. Hanazato, and P. R. Gorski. 1995. Behavioral responses of Daphnia pulex exposed to carbaryl and Chaoborus Kairomone. Environ. Toxicol. Chem. 14:43-50.

Englund, R. A., and Y. Cai. 1999. The occurrence and description of Neocaridina denticulate sinensis (Kemp, 1918) (Crustacea: Decapoda: Atyidae), a new introduction to the Hawaiian Islands. Bishop. Museum. Occasional Papers 58:58-65.

EPA/ROC. 1998. Standard guide for conducting acute tests with shrimps: Static renewal test for Neocaridina denticulata (NIEA B905.10B). Taiwan, Taipei: Environmental Protection Administration of Taiwan. (in Chinese).

Finney, D. J. 1972. Probit analysis. UK, London: Cambribidge University Press. Gagné, F., and C. Blaise. 2000. Organic alkali-labile phosphates in biological materials: A generic assay to detect vitellogenin in biological tissues. Environ. Toxicol. 15:243-247.

Galindo, R. J. G., V. U. Fossato, C. V. Lizarraga, and F. Dolci. 1999. Pesticides in water, sediments, and shrimp from a coastal lagoon off the Gulf of California. Mar: Pollut. Bull. 38:837-841.

Galindo, R. J. G., A. M. Jasso, and C. V. Lizarraga. 1996. Toxic effects of organochlorine pesticides on Penaeus vannamei shrimps in Sinaloa, Mexico. Chemosphere 33:567-575. 
Hasegawa, Y., and E. Hirose. 1993. Hormonal control of sexual differentiation and reproduction in crustacean. Am. Zool. 33:403-411.

Hung, M. S., T. Y. Chan, and H. P. Yu. 1993. Atyid shrimps (Decapoda: Caridea) of Taiwan, with descriptions of three new species. J. Crust. Biol. 13:481-503.

Keith, L. H. 1997. Environmental endocrine disruptors. New York: Wiley.

Kime, D. E., J. P. Nash, and A. P. Scott. 1999. Vitellogenesis as a biomarker of reproductive disruption by xenobiotics. Aquaculture 177:345-352.

Klaassen, C. D. 2001. Casarett and Doull's toxicology, New York: McGraw. Hill.

Maxey, K. M., K. R. Maddipati, and J. Birkmeter. 1992. Interference in enzyme immunoassays. J. Clin. Immunoassay 15:166-120
Pradelles, P., J. Grassi, and J. A. Maclouf. 1985. Enzyme immunoassays of eicosanoids using acetylcholine esterase as label: An alternative to radioimmunoassay. Anal. Chem. 57:1170-1173.

Silvestroni L., and S. Palleschi. 1999. Effects of organochlorine xenobiotics on human spermatozoa. Chemosphere 39:1249-1252.

Taylor M. R., and P. T. C. Harrison. 1999. Ecological effects of endocrine disruption: Current evidence and research priorities. Chemosphere 39:12371248.

Tseng D. Y., Y. N. Chen, G. H. Kou, C. F. Lo, and C. M. Kou. 2001 Hepatopancreas is the extraovarian site of vitellogenin synthesis in black tiger shrimp, Penaeus monodon. Comp. Biochem. Physiol. A 129:909-917. 
Copyright of International Journal of Toxicology is the property of Taylor \& Francis Ltd and its content may not be copied or emailed to multiple sites or posted to a listserv without the copyright holder's express written permission. However, users may print, download, or email articles for individual use. 